\title{
PELAKSANAAN VISI DAN MISI PROGRAM STUDI PENDIDIKAN AGAMA ISLAM DALAM PROSES PEMBELAJARAN PADA FAKULTAS ILMU TARBIYAH DAN KEGURUAN IAIN AMBON
}

\author{
Lilinurinda Daud, Nursaid
}

\begin{abstract}
Abstrak : Program Studi Pendidikan Agama Islam Fakultas IImu Tarbiyah dan Keguruan IAIN Ambon merupakan lembaga yang bergerak di bidang pendidikan dan pengajaran. Dalam menjalankan fungsinya sebagai lembaga pendidikan dibutuhkan suatu perencanaan yang strategis guna mewujudkan tujuan yang telah dirumuskan. Perencanaan tersebut digambarkan dalam visi dan misi Program Studi Pendidikan Agama Islam. Namun kenyataan yang dijumpai dalam proses pembelajaran adalah masih terdapat beberapa dosen yang melaksanakan pembelajaran tidak mengarah kepada pelaksanaan visi dan misi Program Studi. Hal ini terlihat ketika dalam proses perkuliahan masih banyak dosen yang tidak disiplin sehingga proses perkuliahan tidak berjalan dengan efektif. Hasil dari penelitian ini adalah pelaksanaan visi dan misi Program Studi Pendidikan Agama Islam dalam proses pembelajaran dilakukan dengan mengganti kurikulum lama dengan kurikulum baru yakni kurikulum KKNI (Kerangka Kualifikasi Nasional Indonesia) yang disesuaikan dengan visi dan misi Program Studi. Sedangkan faktor penghambatnya adalah minat belajar mahasiswa yang masih kurang, sarana dan prasarana yang belum memadai, buku-buku penunjang mata kuliah yang masih kurang, serta dosen yang tidak disiplin dalam perkuliahan.
\end{abstract}

Kata Kunci: Pelaksanaan Visi dan Misi Program Studi, Proses Pembelajaran.

\section{PENDAHULUAN}

Sebagai lembaga pendidikan, Fakultas IImu Tarbiyah dan Keguruan khususnya Program Studi Pendidikan Agama Islam harus mampu menjalankan perannya dengan baik. Hal itu dapat dilakukan dengan pengelolaan yang terencana dengan baik guna mewujudkan tujuan pendidikan yang telah dirumuskan.

Pengelolaan yang tidak terencana dengan baik akan mengakibatkan hambatan bagi Program Studi Pendidikan Agama Islam dalam menjalankan fungsinya sebagai lembaga pendidikan. Dibutuhkan perencanaan yang strategis untuk mengelolah Program Studi Pendidikan Agama Islam secara efektif dan efisien khususnya dalam proses pembelajaran. Komponen yang terdapat dalam perencanaan tersebut adalah visi dan misi beserta tujuan yang ingin dicapai oleh Program Studi Pendidikan Agama Islam. Perumusan visi dan misi tersebut 
dilakukan dengan harapan agar Fakultas IImu Tarbiyah dan Keguruan khususnya Program Studi Pendidikan Agama Islam memiliki arah kebijakan yang dapat menunjang tercapainya tujuan yang diharapkan.

Kesuksesan suatu lembaga pendidikan dapat dilihat dari hasil evaluasi yang menghasilkan tercapainya tujuan yang ingin dicapai. Untuk membantu tercapainya tujuan yang diharapkan, perlu adanya pengetahuan tentang perumusan visi dan misi serta mengoptimalkannya dalam proses pembelajaran dengan baik dan benar.

Berdasarkan uraian di atas, maka penelitian ini bertujuan untuk mengetahui pelaksanaan visi dan misi Program Studi Pendidikan Agama Islam dalam proses pembelajaran pada Fakultas IImu Tarbiyah dan Keguruan IAIN Ambon

\section{METODE PENELITIAN}

\section{Pendekatan dan Jenis Penelitian}

Pendekatan yang digunakan peneliti pada penelitian ini adalah pendekatan kualitatif. Pendekatan kualitatif adalah suatu proses penelitian dan pemahaman yang berdasarkan pada metodologi yang menyelidiki suatu fenomena sosial dan masalah manusia. Pada pendekatan ini, peneliti menekankan sifat realitas yang terbangun secara sosial, hubungan erat antara peneliti dan subjek yang diteliti. Dalam hal ini, penelitian yang akan dilakukan untuk mendeskripsikan bagaimana pelaksanaan visi dan misi Program Studi Pendidikan Agama Islam dalam proses pembelajaran pada Fakultas IImu Tarbiyah dan Keguruan IAIN Ambon.

Jenis penelitian ini adalah deskriptif kualitatif, yaitu metode penelitian yang bertujuan untuk menggambarkan secara utuh dan mendalam tentang realitas sosial dan berbagai fenomena yang terjadi pada Program Studi Pendidikan Agama Islam yang menjadi subjek penelitian sehingga tergambarkan ciri, karakter, sifat dan model dari fenomena tersebut.

\section{Sumber Data}

Data yang digunakan dalam penelitian ini adalah data kualitatif. Menurut Lofland, sumber data utama dalam penelitian kualitatif ialah kata-kata, dan 
tindakan, selebihnya adalah data tambahan seperti dokumen dan lain-lain. Adapun sumber data yang penulis peroleh adalah sebagai berikut:

\section{1) Data Primer}

Adalah data yang langsung memberikan data kepada pengumpul data. Data primer berupa data melalui observasi dan wawancara.

\section{2) Data Sekunder}

Adalah sumber data yang tidak langsung kepada pengumpul data. Data sekunder dari penelitian ini adalah kepustakaan, berupa buku-buku, jurnal, artikel, dokumen-dokumen Program Studi Pendidikan Agama Islam, literatur, maupun informasi tentang visi, misi, tujuan serta struktur organisasi yang bisa melengkapi dan memperjelas data dalam penelitian ini.

Berikut ini gambar alur model analisis data Milles H. Huberman.

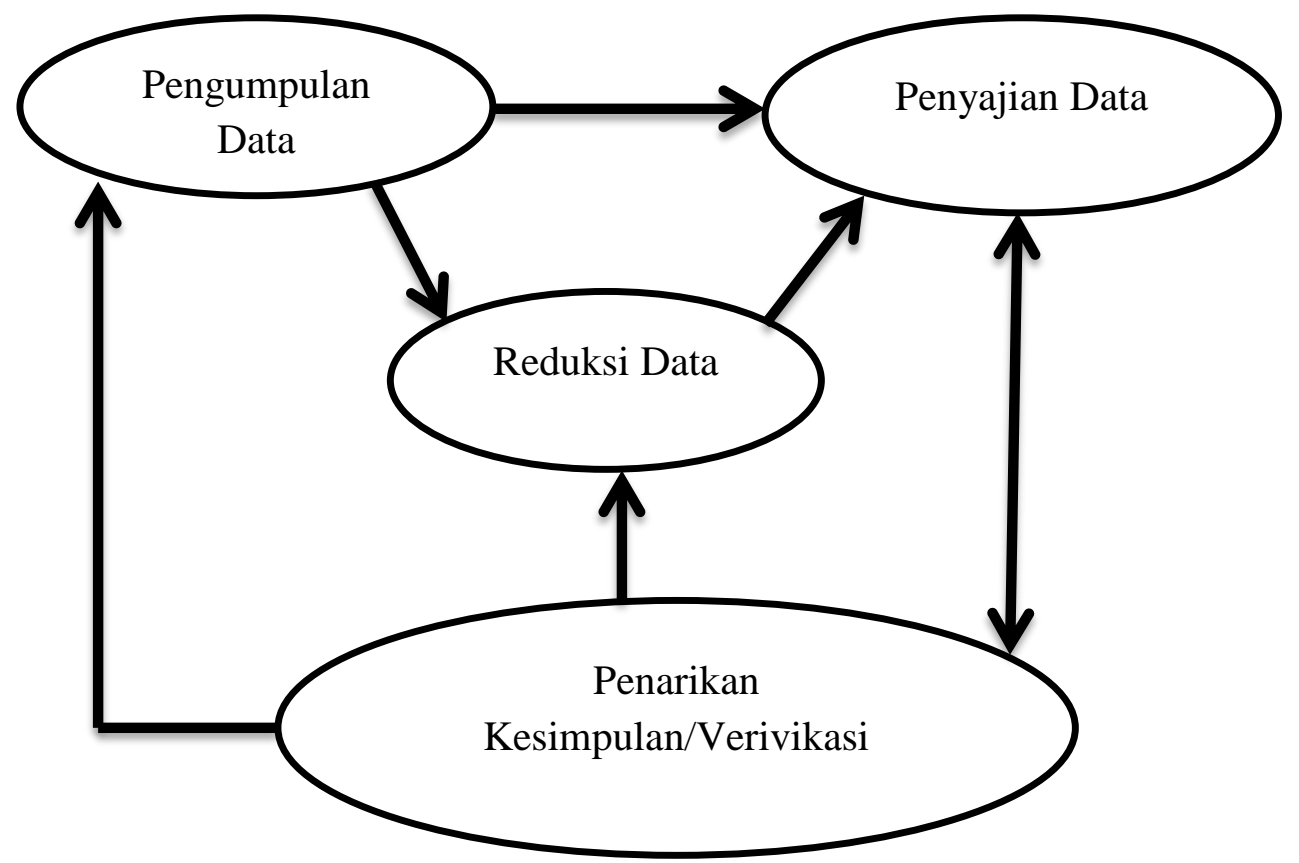




\section{Hasil Penelitian}

1. Pelaksanaan Visi Dan Misi Program Studi Pendidikan Agama Islam dalam Proses Pembelajaran

Program Studi Pendidikan Agama Islam Fakultas IImu Tarbiyah dan Keguruan IAIN Ambon merupakan salah satu lembaga yang bergerak di bidang pendidikan dan pengajaran. Dalam menjalankan fungsinya tentu dibutuhkan suatu perencanaan yang baik guna mencapai tujuan yang telah dirumuskan. Untuk menjalankan perencanaan tersebut, maka diperlukan suatu cara atau strategi khusus. Hal ini dilakukan dengan merumuskan visi dan misi Program Studi Pendidikan Agama Islam. Pelaksanaan visi dan misi tersebut tidak hanya dalam bentuk administrasi semata, tetapi juga dalam proses pembelajaran. Hal ini dimaksudkan karena sasaran dari pelaksanaan visi dan misi tersebut adalah mahasiswa.

Berikut ini jabaran pelaksanaan visi dan misi Program Studi Pendidikan Agama Islam dalam proses pembelajaran.

\section{1) Menyelenggarakan Pendidikan dan Pengajaran Agama Islam Secara Profesional dalam Mengintegrasikan Kelslaman, Keilmuan dan Teknologi}

Program Studi Pendidikan Agama Islam adalah lembaga yang menyelenggarakan proses pendidikan pada tingkat perguruan tinggi di bawah naungan Fakultas IImu Tarbiyah dan Keguruan IAIN Ambon. Sebagai Program Studi yang bergerak pada bidang keagamaan, Program Studi Pendidikan Agama Islam dalam proses pembelajarannya tidak hanya menuntut mahasiswanya untuk pandai dalam bidang keagamaan saja, melainkan mereka juga dituntut untuk pandai dalam bidang teknologi. Dewasa ini, teknologi bukan lagi hal yang baru bagi mahasiswa karena pada setiap aspek yang dilewati, mereka senantiasa diperhadapkan dengan budaya teknologi baik di lingkungan perguruan tinggi maupun di lingkungan tempat tinggalnya.

Program Studi Pendidikan Agama Islam berperan aktif dalam menyiapkan mahasiswanya untuk pandai dalam semua bidang baik itu kelslaman, keilmuan, 
maupun teknologi. Dalam proses pelaksanaannya, Program Studi Pendidikan Agama Islam telah melakukan upaya untuk merangkai ketiga hal tersebut dalam satu bingkai yaitu melalui proses pembelajaran. Hal ini dilakukan dengan menetapkan kurikulum yang didalamnya memuat mata kuliah-mata kuliah yang dapat menunjang profesi mahasiswa Program Studi Pendidikan Agama Islam yang nantinya akan menjadi seorang guru agama, maka mereka dibekali dengan mata kuliah-mata kuliah khusus keagamaan seperti: Ulumul Qur'an, Ulumul Hadits, Ushul Fiqh, Baca Tulis AI-Qur'an, Materi Fiqh I dan II, Materi Hadits I dan II, Materi Al-Qur'an I dan II, Pembelajaran Fiqh I dan II, Pembelajaran Aqidah Akhlak I dan II, Pembelajaran AI-Qur'an Hadits I dan II, Pembelajaran SKI I dan II, dan lain sebagainya. Kemudian untuk mata kuliah keilmuan, mahasiswa Program Studi Pendidikan Agama Islam dibekali dengan mata kuliah yang menunjang keilmua mereka seperti: Civic Education, Bahasa Arab, Bahasa Indonesia, Bahasa Inggris, Perbandingan Pendidikan, Ilmu Pendidikan Islam, Manajemen Pendidikan, Administrasi dan Supervisi Pendidikan, Bimbingan dan Konseling, Metode Penelitian, Pengembangan dan Telaah Kurikulum PAI, Strategi Pembelajaran, Psikologi Pembelajaran, Desain dan Perencanaan Pembelajaran PAI, Evaluasi Pembelajaran, Pemikiran Pendidikan Islam, Teknik Penulisan Skripsi, dan lain sebagainya. Kemudian untuk menunjang kemampuan mahasiswa dalam hal penguasaan teknologi, maka mahasiswa dibekali dengan mata kuliah-mata kuliah yang didalamnya memuat tentang cara mengoperasikan serta mengaplikasikan komputer seperti mata kuliah Pembelajaran PAI Berbasis TIK, serta mata kuliah Media Pembelajaran yang didalamnya memuat tentang bagaimana cara menggunakan media pembelajaran dengan baik dan benar.

Menyelenggarakan pendidikan dan pengajaran agama Islam secara profesional adalah dengan menyiapkan rencana pembelajaran dengan baik di mulai dari menentukan materi, strategi, media dan evaluasi pembelajaran. Dalam pelaksanaannya, tidak semua dosen Program Studi Pendidikan Agama Islam melakukan proses pembelajaran dengan menggunakan strategi maupun media pembelajaran dengan baik. Ada yang menyampikakan materi dengan hanya meggunakan metode ceramah dan tanya jawab saja tanpa menggunakan 
strategi yang menarik dan media yang bervariasi. Media yang biasanya dipakai hanya papan tulis. Jika kita kembali kepada visi dan misi prodi, hal ini jelas belumlah sejalan dengan pelaksanaan visi dan misi tersebut. sebab, dalam visi dan misi tersebut jelas tertera bahwa : menyelenggarakan pendidikan dan pengajaran agama Islam secara profesional dalam mengintegrasikan kelslaman, keilmuan dan teknologi. Mengenai keilmuan, hal tersebut sudah tidak bisa diragukan lagi sebab dosen-dosen yang mengajar pada Prodi PAI sudah sesuai dengan keilmuan mereka masing-masing. Sedangkan untuk mengintegrasikan kelslaman, ada yang sudah melaksanakan dan ada yang masih belum melaksanakan.

\section{2) Mengembangkan Ilmu Pendidikan Agama Islam dan Keguruan Berbasis Multikultural}

Sebagai wujud pengembangan ilmu pendidikan agama Islam dan keguruan berbasis multikultural, maka Program Studi Pendidikan Agama Islam melakukan pergantian kurikulum lama dengan kurikulum KKNI. Dengan pergantian kurikulum ini, maka secara otomatis mata kuliahnya pun ikut berubah. Dari perubahan kurikulum tersebut, maka mata kuliah Pendidikan Multikultural yang sebelumnya tidak ada kemudian dimasukkan dalam daftar mata kuliah yang berhak diikuti oleh setiap mahasiswa. Hal ini merupakan bentuk pelaksanaan visi dan misi Program Studi Pendidikan Agama Islam dalam proses pembelajaran.

Sekalipun demikian, multikultural sejatinya tidak hanya dapat dilihat dari keberagaman agama pada ruang lingkup kampus IAIN Ambon. Akan tetapi multikultural juga dapat dilihat dari keberagaman suku, budaya dan bahasa dari setiap mahasiswa, dosen dan staf administrasi yang ada di kampus IAIN Ambon. Begitu juga halnya dengan progam studi Pendidikan Agama Islam. Mahasiswa yang berasal dari berbagai daerah tentunya memiliki budaya dan bahasa yang berbeda-beda pula. Tidak hanya itu, keberagaman itu juga dapat dilihat dari perbedaan pendapat setiap mahasiswa dalam menyikapi berbagai persoalan yang dibahas dalam forum-forum diskusi yang terjadi dalam proses pembelajaran. 


\section{3) Melaksanakan Penelitian di Bidang IImu Pendidikan Agama Islam dan Keguruan Secara Integratif Yang Unggul dan Kompetitif}

Sebagai wujud dari melaksanakan penelitian di bidang ilmu pendidikan agama Islam dan keguruan, Program Studi Pendidikan Agama Islam Fakultas IImu Tarbiyah dan Keguruan IAIN Ambon mewajibkan setiap mahasiswanya untuk melaksanakan penelitian baik itu di bidang keagamaan maupun keilmuan. Untuk memberikan pemahaman serta memudahkan mahasiswa dalam melakukan proses penelitiannya nanti, maka Program Studi Pendidikan Agama Islam Fakultas IImu Tarbiyah dan Keguruan IAIN Ambon menyusun kurikulum yang memuat mata kuliah metode penelitian untuk tingkat semester $\mathrm{V}$. Sedangkan untuk memudahkan mahasiswa dalam menyusun skripsi, mahasiswa dibekali dengan mata kuliah teknik penulisan skripsi.

4) Melaksanakan Pengabdian Kepada Masyarakat Sebagai Aplikasi IImu Pendidikan Agama Islam Berbasis Multikultural

Ketika mahasiswa sudah berada pada semester VI mereka sudah dipersiapkan dengan berbagai bekal untuk melaksanakan pengabdian kepada masyarakat, salah satunya dengan diberikan mata kuliah micro teaching untuk mempersiapkan mereka menjadi guru pada saat terjun di lapangan untuk melaksanakan program PPKT (Praktek Profesi Keguruan Terpadu). Dan ketika mahasiswa sudah semester VII, disitulah mereka kemudian dipersiapkan dengan berbagai pembekalan untuk turun di lokasi tempat mereka melaksanakan pengabdian.

ketika penempatan lokasi, mahasiswa tidak sedikitpun diperbolehkan untuk memilih lokasi tempat mereka melaksanakan pengabdian. Mahasiswa hanya diperbolehkan untuk mengiyakan setiap keputusan panitia PPKT. Di manapun lokasinya nanti, mahasiswa tidak diberikan ijin untuk protes terhadap keputusan yang telah ditetapkan oleh panitia. Hal ini dilakukan agar mahasiswa benar-benar memiliki rasa tanggung jawab terhadap apa yang telah di amanahkan oleh panitia. Di lokasi itulah, mahasiswa kemudian diperhadapkan pada kenyataan yang sangat jauh berbeda dengan apa yang telah mereka alami selama di perguruan tinggi. Jika sebelumnya ketika mereka melakukan praktek 
mengajar di kelas muridnya adalah mahasiswa, maka di lokasi yang mereka tempati mereka benar-benar mengajar siswa yang pada dasarnya memiliki sikap, karakter, dan motivasi yang berbeda-beda dalam mengikuti proses pembelajaran.

Menghadapi kenyataan tersebut, maka Program Studi Pendidikan Agama Islam Fakultas IImu Tarbiyah dan Keguruan IAIN Ambon melakukan berbagai macam upaya untuk mempersiapkan mahasiswanya menjadi calon guru yang berkompeten khususnya di bidang agama Islam. Melalui kurikulum yang menyajikan mata kuliah-mata kuliah yang memberikan penguatan untuk menjadi seorang guru, mahasiswa diwajibkan untuk mengikuti mata kuliah khusus pembelajaran seperti: Pembelajarn Fiqh I untuk SMP/MTs, Pembelajaran Fiqh II untuk SMA/MA, Pembelajaran Al-Qur'an Hadits I untuk SMP/MTs, Pembelajaran Al-Qur'an Hadits II untuk SMA/MA, Pembelajaran Aqidah Akhlak I untuk SMP/MTs, Pembelajaran Aqidah Akhlak II untuk SMA/MA, Pembelajaran SKI I untuk SMP/MTs, dan Pembelajaran SKI II untuk SMA/MA. Melalui mata kuliahmata kuliah inilah, mahasiswa benar-benar dipersipakan untuk menjadi seorang guru di manapun lokasi yang mereka tempati. Melalui mata kuliah tersebut juga, mahasiswa tidak hanya dibekali untuk menjadi guru agama pada sekolah yang bernuansa agama saja seperti MTs atau MA, tetapi mereka juga dibekali untuk menjadi guru pada sekolah umum seperti SMP, SMA maupun SMK. Hal ini membuktikan bahwa Program Studi Pendidikan Agama Islam Fakultas IImu Tarbiyah dan Keguruan IAIN Ambon benar-benar menyiapkan mahasiswanya untuk hidup berdampingan dengan semua etnis pada lapisan masyarakat. Terkait dengan mampu tidaknya mahasiswa dalam melaksanakan pengabdian, hal itu di kembalikan kepada mahasiswa itu sendiri.

Sebagai upaya mengaplikasikan IImu Pendidikan Agama Islam berbasis multikultural, maka pada tahun 2017, Fakultas IImu Tarbiyah dan Keguruan IAIN Ambon ketika melakukan survey lokasi untuk penempatan mahasiswa yang melakukan Praktek Profesi Keguruan Terpadu (PPKT), maka dipilihlah salah satu lokasi atau sekolah yang di dalamnya tidak hanya menganut satu kepercayaan atau agama melainkan menganut 3 agama yaitu Islam, Kristen 
Protestan dan Kristen Katolik. Sekolah tersebut adalah SMA Negeri Unggulan Siwalima Ambon yang berlokasi di jln. Waenapu, Waiheru, Ambon.

5) Menjalin Kerja sama dengan Lembaga Kependidikan dan non Kependidikan di Tingkat Lokal, Nasional dan Internasional

Menjalin kerja sama dengan lembaga kependidikan dan non kependidikan merupakan faktor yang sangat penting dalam menunjang dan meningkatkan kualitas suatu perguruan tinggi, semakin banyak kerja sama maka akan semakin memperkaya pengalaman serta pengetahuan. Apalagi bekerja sama dengan perguruan tinggi internasional, tentunya hal tersebut akan semakin bagus pula.

Pada tahun 2017, Program Studi Pendidikan Agama Islam Fakultas IImu Tarbiyah dan Keguruan IAIN Ambon pernah menjalin kerja sama dengan perguruan tinggi yang ada di negeri Jiran, Malasya. Akan tetapi hal tersebut kemudian tidak ditindak lanjuti sebab kerja sama yang terjalin masih kerja sama antar rektor.

1. Faktor Pendukung dan Penghambat dalam Pelaksanaan Visi dan Misi Program Studi Pendidikan Agama Islam dalam Proses Pembelajaran

\section{a. Faktor Pendukung}

Berdasarkan penuturan dari Ketua Program Studi Pendidikan Agama Islam Fakultas IImu Tarbiyah dan Keguruan IAIN Ambon, adapun faktor yang mendukung Program Studi Pendidikan Agama Islam dalam pelaksanaaan visi dan misinya dalam proses pembelajaran adalah:

"Kalau faktor pendukung yang pertama kurikulumnya. Kita selalu berusaha untuk menerapkan kurikulum yang sesuai dengan visi dan misi Program Studi. Kemudian jumlah dan kualifikasi dosen. karena untuk tiga Program Studi pada Fakultas Tarbiyah jumlah dosen yang terbanyak adalah PAI. Ada beberapa yang pendidikannya sudah S3 dan mereka mengajar berdasarkan bidangnya masing-masing."

Berdasarkan hasil wawancara, dapat diketahui bahwa ada dua faktor yang mendukung pelaksanaan visi dan misi Program Studi dalam proses pembelajaran yang pertama adalah kurikulum. Program Studi Pendidikan Agama 
Islam selalu berupaya untuk melakukan revisi terhadap kurikulumnya selama lima tahun sekali yang disesuaikan dengan visi dan misi Program Studi. Hal ini dilakukan agar kurikulum yang digunakan selalu mengikuti kebutuhan stakheholder agar kurikulum tersebut mampu menjawab dan mewujudkan impian dan cita-cita dari Program Studi Pendidikan Agama Islam yang tertuang dalam visi dan misi.

Faktor pendukung yang kedua adalah jumlah dan kualifikasi dosen yang sesuai dengan bidangnya masing-masing. Dosen merupakan faktor penentu kedua dalam melaksanakan visi dan misi Program Studi Pendidikan Agama Islam khusunya dalam proses pembelajaran. Hal ini sesuai dengan penuturan dari Sekertaris Program Studi Pendidikan Agama Islam berikut ini:

"Untuk faktor pendukungnya alhamdulillah PAI dosennya banyak. Jadi kalau untuk sumber daya manusianya kita sudah banyak. Dan memang untuk tiga Program Studi yang ada di Fakultas Tarbiyah kita yang dosennya paling banyak dan dosen yang sudah S3 juga alhamdulillah sudah banyak. Jadi itu yang menjadi faktor pendukung kita dalam melaksanakan visi dan misi Program Studi”.

Berdasarkan hasil wawancara, dapat diketahui bahwa faktor pendukung kedua dalam pelaksanaan visi dan misi Program Studi dalam proses pembelajaran adalah dengan kualifikasi dosen yang sudah sesuai dengan bidangnya masing-masing. Walaupun memang masih terdapat mata kuliah-mata kuliah yang dosen tetapnya tidak ada tetapi hal itu sudah diantisipasi dengan dosen lain yang memang mampu mengajar di bidang tersebut.

\section{b. Faktor Penghambat}

\section{a) Kurangnya minat dan motivasi belajar mahasiswa}

Berdasarkan hasil pengamatan yang dilakukan peneliti menunjukkan bahwa faktor penghambat dalam pelaksanaan visi dan misi Program Studi Pendidikan Agama Islam dalam proses pembelajaran adalah sifat acuh tak acuh mahasiswa dalam mengikuti proses perkuliahan. Hal ini terlihat dengan masih 
banyak mahasiswa yang datang terlambat untuk mengikuti perkuliahan. Selain terlambat, mahasiswa juga sering pasif dalam perkuliahan. Padahal sejatinya proses perkuliahan adalah proses dimana terjadi timbal balik antara dosen dengan mahasiswa. Akhirnya tidak dapat dipungkiri, yang aktif dalam perkuliahan hanya mahasiswa-mahasiswa yang menganggap bahwa belajar itu penting dan keaktifan dalam perkuliahan adalah kunci untuk mendapatkan pengetahuan. Karena pada dasarnya dosen tidak mengetahui sampai sejauh mana pengetahuan yang diperoleh mahasiswa tersebut, tapi setelah melalui diskusi dan tanya jawab, pengetahuan mahasiswa kemudian akan muncul dengan sendirinya.

\section{b) Sarana dan prasarana yang belum memadai}

Selain itu, faktor pengambat lainnya adalah sarana dan prasarana yang kurang memadai. Misalnya laboratorium Micro Teaching yang masih belum dimiliki oleh Program Studi hingga saat ini.

Dalam suatu lembaga pendidikan, sarana dan prasarana merupakan faktor penentu dalam setiap kegiatan yang dilakukan. Kekurangan sarana dan prasarana akan mengakibatkan pencapaian yang tidak maksimal. Sarana adalah segala sesuatu yang mendukung secara langsung terhadap kelancaran proses pembelajaran, misalnya media pembelajaran, alat-alat pelajaran, perlengkapan sekolah, dan lain sebagainya. Sedangkan prasarana adalah segala sesuatu yang secara tidak langsung dapat mendukung keberhasilan proses pembelajaran, misalnya jalan menuju sekolah, penerangan sekolah, kamar kecil, dan lain sebagainya. Kelangkapan sarana dan prasarana akan membantu guru dalam penyelenggaraan proses pembelajaran, dengan demikian sarana dan prasarana merupakan komponen penting yang dapat memengaruhi proses pembelajaran.

\section{c) Dosen yang tidak disiplin pada saat perkuliahan}

Kedisiplinan dosen dalam perkuliahan menjadi masalah besar dalam setiap perkuliahan yang dilewati oleh mahasiswa. Seolah ini menjadi lagu wajib dalam setiap perkuliahan. Kurangnya kedisiplinan dosen ini dipengaruhi oleh 
tugas serta tanggung jawab yang diemban oleh dosen tersebut. Karena memangku jabatan yang mengakibatkan dosen tersebut sering keluar kota serta banyaknya kegiatan yang harus diikuti, sehingga mahasiswa pun menjadi korban yang pada akhirnya proses perkuliahan tidak berjalan dengan efektif. Jika alasan ketidakhadiran itu karena sebuah jabatan, maka tidaklah etis jika mereka kemudian mengorbankan mahasiswanya dalam perkuliahan. Karena tugas dan tanggung jawab seorang dosen adalah mengajar dan mendidik mahasiswa. Jika kemudian mereka mengorbankan mahasiswa, maka akan lebih baik jika mereka menggunakan asisten. Sebab, hal tersebut adalah alternatif termudah agar mahasiswa tidak selamanya menjadi korban. Ataupun dosen tersebut seharusnya lebih terfokus kepada satu arah, dalam hal ini dosen tersebut harus memilih untuk menjadi seorang dosen atau menjadi seorang pejabat. Sebab tidak mungkin seseorang menjalankan dua kewajibannya dalam waktu yang bersamaan.

Jika diperhatikan lebih lanjut, kurangnya minat dan motivasi belajar dari mahasiswa tidak hanya dipengaruhi oleh kurangnya motivasi dari dalam dirinya, melainkan juga dari dosen. Karena menjadi seorang guru tidak hanya harus pandai dalam mengajar, tetapi juga harus pandai dalam memberikan motivasi. Tidak hanya itu, seorang guru juga dituntut untuk mampu menjadi contoh dan teladan kepada peserta didik. Memberikan contoh tidak hanya melalui pengetahuan, tetapi juga melalui tindakan, dalam hal ini adalah kedisiplinan. Bagaiman bisa mahasiswa itu memiliki motivasi dan semangat untuk belajar, jika dosen yang mengajarnya saja senantiasa melakukan tindakan yang mereka tidak sukai. Ketika ketidakdisiplinan itu hanya terjadi sekali, itu masih bisa dimaklumi dan dimengerti. Akan tetapi jika itu sudah terjadi secara berulangulang maka yang muncul adalah rasa ketidaksukaan terhadap dosen tersebut. Akibatnya, mahasiswapun akan malas dan kehilangan minat dan motivasinya untuk belajar.

Dosen yang baik adalah dosen yang mampu menjadi uswah atau teladan bagi mahasiswa. Teladan yang diberikan itu tidak hanya teladan dengan ilmu yang dimiliknya, tetapi juga dengan kedisiplinan yang senantiasa mereka 
tunjukkan kepada mahasiswa melalui proses pembelajaran di kelas. Tepat waktu dalam perkuliahan yang sesuai dengan kesepakatan pada awal perkuliahan yang disepakati melalui kontrak perkuliahan harus menjadi landasan utama dalam menjalankan proses pembelajaran. Sebab, seseorang itu akan dinilai bertanggung jawab ketika ia mampu melaksanakan apa yang telah di ucapkannya. Tidak akan dipandang baik mereka yang hari ini berkata tentang suatu hal akan tetapi besoknya ia tidak mampu untuk melakukan apa yang telah di ucapkannya itu. Begitulah adanya realita yang masih dijumapi pada sebagian dosen Program Studi Pendidikan Agama Islam yang sampai pada detik ini masih bermasalah pada tingkat kedisiplinan mengajar. Sehingga mahasiswa pun menjadi korban yang tidak bisa dihindari lagi.

\section{Kesimpulan}

Berdasarkan hasil penelitian tersebut dapat disimpulkan bahwa:

Pelaksanaan visi dan misi Program Studi Pendidikan Agama Islam dalam proses pembelajaran dilakukan dengan menyusun kurikulum yang sesuai dengan visi dan misi Program Studi. Berbagai mata kuliah yang disajikan dikemas sedemikian rupa sehingga visi dan misi Program Studi dapat terlaksana secara optimal dalam proses pembelajaran. Adapun jabaran pelaksanaan visi dan misi Program Studi Pendidikan Agama Islam Fakultas IImu Tarbiyah dan Keguruan IAIN Ambon adalah sebagai berikut:

a. Visi

Menjadi Program Studi Pendidikan Agama Islam yang unggul dalam pengintegrasian kelslaman, keilmuan, kebudayaan dan teknologi di Indonesia bagian timur tahun2020.

b. Misi

1) Menyelenggarakan pendidikan dan pengajaran agama Islam secara profesional dalam mengintegrasikan kelslaman, keilmuan dan teknologi, belum terlaksana secara maksimal, sebab masih terdapat beberapa dosen yang melakukan proses pembelajaran tidak sesuai dengan pernyataan visi dan misi tersebut. 
2) Mengembangkan ilmu pendidikan agama Islam dan keguruan berbasis multikultural;

3) Melaksanakan penelitian di bidang ilmu pendidikan agama Islam dan keguruan secara integratif yang unggul dan kompetitif;

4) Melaksanakan pengabdian kepada masyarakat sebagai aplikasi ilmu pendidikan agama Islam berbasis multikultural;

5) Menjalin kerja sama dengan kembaga kependidikan dan non kependidikan di tingkat lokal, nasional dan internasional.

1. Faktor pendukung dan penghambat Program Studi Pendidikan Agama Islam dalam pelaksanaan visi dan misi dalam proses pembelajaran adalah sebagai berikut:

a. Faktor pendukung yakni dari segi kurikulum yang dinilai sudah sesuai dengan visi dan misi Program Studi dan kualifikasi dosen yang sudah sesuai dengan bidangnya masing-masing.

b. Faktor penghambat yakni kurangnya sarana dan prasarana, rendahnya minat dan motivasi belajar mahasiswa, serta kurangnya kedisiplinan mengajar dosen.

\section{DAFTAR PUSTAKA}

[1] A. Maolani, Rukaesih dan Ucu Cahyana. Metodologi Penelitian

[2] A. M, Sardiman. Interaksi dan Motivasi Belajar Mengajar. Jakarta:

[3] Amina Hatalea, Siti. "Peran Orang Tua dalam Pembentukan Karakter

[4] Burhan Bungin, M. Penelitian Kualitatif. Jakarta: Kencana, 2015.

[5] Halima. "Implementasi Visi Misi Madrasah dalam Meningkatkan Proses

[6] Herdiansyah, Haris. Wawancara, Observasi, dan Focus Groups; Sebagai

[7] Iriani Jailan, Desi. :Peranan Program Studi Pendidikan Agama 
Islam

[8] Karman, M. dkk. Teknik Penulisan Karya IImiah. Jakarta: Hilliana Press,

[9] Khodijah, Nyayu. Psikologi Pendidikan. Jakarta: PT Raja Grafindo

[10] Moleong J, Lexy. Metodologi Penelitian Kualitatif. Bandung: Remaja

[11] Muhaimin dkk. Manajemen Pendidikan; Aplikasinya dalam Penyusunan

[12] Musfah, Jejen. Manajemen Pendidikan; Teori, Kebijakan, dan Praktik.

[13] Nata, Abuddin. Manajemen Pendidikan; Mengatasi Kelemahan

[14] Noor, Juliansyah. Metode Penelitian; Skripsi, Tesis, Disertasi, dan Karya

[15] Putra, Nusa. Metode Penelitian Kualitatif Pendidikan. Jakarta: Raja

[16] Rahman Getteng. Abd. Menuju Guru Profesional dan Beretika.

[17] Rivai, Veitzal dan Sylviana Murni. Education Management. Jakarta: Raja

[18] Sanjaya, Wina. Strategi Pembelajaran Berorientasi Standar Proses

[19] --------, Perencanaan dan Desain Sistem Pembelajaran. Jakarta:

[20] --------, Strategi Pembelajaran Berorientasi Standar Proses Pendidikan.

[21] Salim, Moh. Haitami dan Syamsul Kurniawan. Studi IImu Pendidikan

[22] Nurdin, Syafrudin dan Adriantoni. Kurikulum Pembelajaran. Jakarta: 2002 